\title{
Kebijakan Hukum terhadap Tanggung Jawab Transnasional Corporations (TNCs) atas Pelanggaran Hak Menikmati Lingkungan yang Sehat di Indonesia
}

\author{
Sri Wartini \\ Jamaludin Ghafur \\ Fakultas Hukum Universitas Islam Indonesia \\ Jl. Tamansiswa No. 158 Yogyakarta \\ sri.wartini67@yahoo.com ; james.fhuii@gmail.com.
}

\begin{abstract}
The problems in this study, namely: first, how the policy of the law towards the responsibility of TNCs related to the violation of right of enjoying a healthy environment in Indonesia? Secondly, why the need for a model law policy against liability for infringement TNCs enjoyed a healthy environment in Indonesia? This research is normative. The approach used is the conceptual approach and legislation. Results of this study concluded that: first, the legal policy towards the responsibility of TNCs for violations of the right of enjoying a healthy living environment have not been explicitly included in the national regulations of Indonesia. Second, the model of law policy towards the responsibility of TNCs related to the violation of right of enjoying a healthy environment is necessary.
\end{abstract}

Keywords: Human rights, the right of enjoying a healthy environment, constitutional rights and transnational corporations.

\begin{abstract}
Abstrak
Permasalahan dalam penelitian ini, yaitu: pertama, bagaimana kebijakan hukum terhadap tanggung jawab TNCs atas pelanggaran hak menikmati lingkungan hidup yang sehat di Indonesia? Kedua, mengapa perlu adanya model kebijakan hukum terhadap tanggung jawab TNCs atas pelanggaran hak menikmati lingkungan yang sehat di Indonesia? Penelitian ini merupakan penelitian normatif. Adapun pendekatan yang digunakan adalah pendekatan konseptual dan perundang-undangan. Hasil penelitian ini menyimpulkan bahwa: pertama, kebijakan hukum terhadap tanggung jawab TNCs atas pelanggaran hak untuk menikmati lingkungan hidup yang sehat belum dimasukkan secara ekplisit dalam peraturan nasional Indonesia. Kedua, model kebijakan hukum terhadap tanggung jawab TNCs atas pelanggaran hak menikmati lingkungan hidup yang sehat diperlukan.
\end{abstract}

Kata kunci: Hak asasi manusia, hak menikmati lingkungan yang sehat, hak konstitusi dan perusahaan transnasional. 


\section{Pendahuluan}

Bumi ini terancam dengan berbagai kasus lingkungan baik yang disebabkan oleh kegiatan pembangunan suatu negara atau oleh perusahaan Transnational Corporations (TNCs) yang menanamkan modalnya di negara berkembang. Kekuatan ekonomi perusahaan Transnasional (Transnational Corporations) selanjutnya akan disebut TNCs tidak diragukan lagi. Perusahaan ini merupakan penggerak ekonomi global. ${ }^{1}$ TNCs memiliki kemampuan untuk mengatur dan menguasai perdagangan internasional, investasi dan alih teknologi. Namun demikian tidak jarang bahwa TNCs yang berada di negara berkembang seperti di Indonesia telah berkontribusi terhadap permasalahan lingkungan baik itu berupa kerusakan lingkungan maupun pencemaran lingkungan, sehingga hak warga negara untuk menikmati lingkungan hidup yang sehat dilanggar.

Hak untuk menikmati lingkungan hidup yang sehat sekarang ini sudah diakui sebagai bagian dari hak asasi manusia baik dalam konvensi yang bersifat regional maupun yang bersifat global, bahkan sudah diakui sebagai hak konstitusi diberbagai negara termasuk di Indonesia yang diatur dalam Pasal $28 \mathrm{H}$ UUD 1945 setelah amandemen yang ke-4 tahun 2002 (selanjutnya akan disebut UUD 1945). Namun demikian dari berbagai kasus yang terjadi di beberapa negara berkembang kurang sekali adanya perlindungan hukum yang diberikan kepada warga negara untuk menikmati lingkungan hidup yang sehat, terutama dilakukan oleh TNCs yang bergerak dalam bidang pertambangan seperti misalnya, Royal Duch/Shell's Oil Production di Nigeria, ${ }^{2}$ dan BHP Billiton's Coper Mining di Papua New Guinea, dan Equador, yang telah mempekerjakan buruh anak serta mencemarkan ekosistem sehingga membahayakan kesejahteraan penduduk asli yang bergantung pada ekosistem tersebut. Di Indonesia misalnya, pencemaran lingkungan dilakukan oleh PT Freeport Mc Moran dan PT Newmont.

\footnotetext{
${ }^{1}$ David Kinley \& Junko Tadaki, "From Talk to Walk: The Emergence of Human Rights Responsibilities for Corporations at International Law”, Virginia Journal of International Law, (Summer 2004), Vol. 44, hlm. 939.

2 Oscar Omar Salazar-Duran, "A Human Rights Approach to Corporate Accountability and Environmental Litigation”, University of San Francisco Law Review, Vol. 43, 2009, hlm.734.
} 
Kalau dilihat dari perspektif hukum internasional TNCs bukan merupakan subyek hukum internasional, sehingga sebagai konsekuensinya TNCs tidak dapat dikenakan sanksi berdasarkan ketentuan hukum internasional. Oleh karena itu, hukum internasional tidak dapat memberikan perlindungan hukum terhadap hak untuk menikmati lingkungan hidup yang sehat sebagai bagian dari hak asasi manusia atau sering disebut sebagai generasi ketiga hak asasi manusia yang bersifat komunal dan merupakan hak solidaritas sebagaimana hak tersebut diatur dalam International Covenant on Economic, Social and Cultural Rights ( ICCPR) yang sudah diratifikasi oleh pemerintah Indonesia dengan UU Nomor 12 Tahun 2005.

Oleh karena itu, jika TNCs tidak dapat dikenakan sanksi berdasarkan ketentuan hukum internasional maka seharusnya negara dimana TNCs itu berada memberikan sanksi berdasarkan ketentuan hukum nasionalnya kepada TNCs yang berada di negaranya, karena berdasarkan hukum internasional negara berkewajiban untuk melindungi hak asasi manusia, termasuk hak untuk menikmati lingkungan hidup yang sehat yang telah diakui sebagai hak asasi. Akan tetapi dalam kenyataannya, negara dimana TNCs itu berada jarang sekali yang memberikan sanksi yang tegas terhadap TNCs yang telah melanggar hak menikmati lingkungan hidup yang sehat.

Banyaknya kasus pelanggaran hak untuk menikmati lingkungan hidup yang sehat di berbagai negara berkembang yang dilakukan oleh TNCs tidak tersentuh oleh hukum baik oleh hukum internasional maupun hukum nasional. Hal ini dipengaruhi oleh kebijakan hukum yang dimiliki oleh negara-negara tersebut. Kebijakan hukum yang dimiliki oleh negara berkembang seperti di Indonesia lebih berpihak kepada kepentingan kemajuan ekonomi dibandingkan perlindungan lingkungan termasuk hak untuk menikmati lingkungan hidup yang sehat. Oleh karena itu, perlu adanya suatu model kebijakan hukum yang dilakukan oleh negara berkembang terhadap tanggung jawab TNCs yang telah melanggar hak menikmati lingkungan hidup yang sehat.

Berkaitan dengan kebijakan hukum terhadap tanggung jawab TNCs maka pemerintah harus melakukan suatu pengaturan yang holistik terhadap tanggung jawab TNCs di Indonesia atas pelanggaran hak untuk menikmati lingkungan yang sehat di Indonesia yang merupakan hak konstitusi dan hak asasi manusia. 
TNCs yang melaksanakan kegiatannya di Indonesia tentu tidak lepas dari berbagai peraturan perundang-undangan di Indonesia yang harus ditaatinya, baik itu UU tentang Penanaman modal asing, UU Perseroan Terbatas, UU lingkungan, UU Sumber Daya Alam maupun UU Minyak dan Gas Bumi tergantung di bidang apa TNCs ini melaksanakan kegiatannya. Dalam penelitian ini hanya akan dibatasi pada aktivitas TNCs yang melaksanakan usahanya di bidang pertambangan Minyak dan Gas Bumi.

Model Kebijakan hukum dalam konteks ini adalah suatu model kebijakan yang rasional untuk dapat dilaksanakan dan adanya keberpihakan pemerintah untuk melindungi hak menikmati lingkungan hidup yang sehat. Kebijakan yang dibuat oleh pemerintah untuk mencapai tujuan bagi perlindungan hak menikmati lingkungan hidup yang sehat akan terwujud kalau didukung oleh perangkat peraturan yang memadai, institusi yang bertanggung jawab dalam melaksanakan kewenangannya dan partisipasi masyarakat.

Oleh karena itu, dengan adanya model kebijakan hukum terhadap tanggung jawab TNCs di negara berkembang yang telah melanggar hak menikmati lingkungan hidup yang sehat seperti halnya di Indonesia, akan menjadi pedoman bagi pemerintah untuk membuat peraturan lebih lanjut dan juga mengimplementasikan peraturan tersebut. Berbagai kasus pencemaran lingkungan yang terjadi di Indonesia, antara lain dilakukan oleh PT Newmont dan PT Freeport, menunjukkan bahwa TNCs tidak segan untuk melakukan pelanggaran hak untuk menikmati lingkungan hidup yang sehat, karena dari segi peraturan perundang-undangan dan kebijakan hukum yang dibuat oleh pemerintah belum diimplementasikan dengan baik.

Penelitian ini diawali dengan uraian yang bermaksud, pertama, menyampaikan latar belakang hubungan timbal balik antara hak untuk hidup dan hak untuk menikmati lingkungan yang sehat dalam perpektif hukum HAM. Kedua menganalisis kebijakan hukum terhadap tanggung jawab TNCs atas hak menikmati lingkungan hidup yang sehat di Indonesia. Berikutnya dipaparkan, perlunya model kebijakan hukum tanggung jawab TNCs atas pelanggaran hak menikmati lingkungan hidup yang sehat di Indonesia, kedudukan TNCs dalam hukum internasional dan nasional, dan diikuti instrumen internasional dan 
nasional untuk perlindungan hak menikmati lingkungan hidup yang sehat, serta diakhiri dengan simpulan.

\section{Rumusan Masalah}

Dari latar belakang masalah yang telah dipaparkan, rumusan masalah yang hendak dijawab dalam penelitian ini adalah: pertama, bagaimana kebijakan hukum terhadap tanggung jawab TNCs atas pelanggaran hak untuk menikmati lingkungan hidup yang sehat di Indonesia? Kedua, mengapa perlu adanya model kebijakan hukum terhadap tanggung jawab TNCs atas pelanggaran hak untuk menikmati lingkungan hidup yang sehat di Indonesia?

\section{Tujuan Penelitian}

Penelitian ini bertujuan untuk, pertama, menganalisis kebijakan hukum terhadap tanggung jawab TNCs atas pelanggaran hak untuk menikmati lingkungan hidup yang sehat di Indonesia. Kedua, untuk menganalisis perlunya model kebijakan hukum terhadap tanggung jawab TNCs atas pelanggaran hak untuk menikmati lingkungan hidup yang sehat di Indonesia.

\section{Metode Penelitian}

Jenis penelitian ini adalah penelitian hukum normatif, karena peneliti melakukan penelitian dengan studi literatur, peraturan perundang-undangan dan instrumen internasional yang berhubungan dengan objek yang diteliti untuk mencari jawaban atas masalah yang diteliti.

Objek dalam penelitian ini adalah kebijakan hukum terhadap tanggung jawab TNCs atas pelanggaran hak untuk menikmati lingkungan hidup yang sehat di Indonesia, dan model kebijakan hukum terhadap tanggung jawab TNCs atas pelanggaran hak untuk menikmati lingkungan hidup yang sehat di Indonesia.

Penelitian ini menggunakan teknik pengumpulan bahan hukum yang dilakukan melalui studi pustaka dan wawancara pada narasumber, yakni 
mengkaji instrumen internasional dan peraturan perundang-undangan Indonesia yang berkaitan dengan kebijakan terhadap tanggung jawab TNCs atas pelanggaran hak menikmati lingkungan hidup yang sehat di Indonesia.

Pendekatan yang digunakan adalah pendekatan perundang-undangan, (statute approach) dan pendekatan konseptual (conceptual approach), Penelitian ini dianalisis secara kualitatif, dan dipaparkan dalam bentuk deskriptif analitis.

\section{Hasil Penelitian dan Pembahasan}

Kebijakan Hukum terhadap Tanggung Jawab TNCs atas Pelanggaran Hak Menikmati Lingkungan Hidup yang Sehat di Indonesia

Menurut M. Irfan Islami, kebijakan pemerintah (negara) adalah serangkaian tindakan yang ditetapkan dan dilaksanakan atau tidak dilaksanakan oleh pemerintah yang mempunyai tujuan atau berorientasi pada tujuan tertentu demi kepentingan seluruh masyarakat. ${ }^{3}$ Berdasarkan jenisnya, kebijakan pemerintah (public policy) dapat dibagi menjadi dua kelompok yaitu kebijakan dalam bentuk peraturan-peraturan pemerintah yang tertulis dalam bentuk peraturan perundangan, dan peraturan-peraturan tidak tertulis namun disepakati, yaitu yang disebut sebagai konvensi-konvensi. ${ }^{4}$ Kebijakan pemerintah ini juga mencakup rencana aksi, yang meliputi program dan kegiatan untuk mencapai tujuan-tujuan yang telah ditentukan.

Dengan demikian, tindakan pemerintah dalam menyusun dan membentuk suatu peraturan perundang-undangan merupakan salah satu bentuk pengambilan kebijakan. Dalam literatur ilmu hukum, kebijakan hukum diartikan sama dengan politik hukum. Menurut Muhammad Akib, secara etimologis istilah politik hukum merupakan terjemahan dari istilah hukum Belanda rechtspolitiek, yang merupakan bentukan dari dua kata: recht dan politiek. Dalam bahasa Indonesia kata recht berarti hukum, sedangkan kata politiek di dalamnya terkandung pula arti beleid, yang biasanya diterjemahkan sebagai kebijaksanaan

${ }^{3}$ M. Irfan Islami, Prinsip Prinsip Perumusan Kebijakan Negara, Bumi Aksara, Jakarta, 2003, hlm. 25

4 Riant Nugroho Dwijowijoto, Kebijakan Publik: Formulasi, Implementasi dan Evaluasi, Elex Media Komputindo, Jakarta, 2003, hlm. 5 
atau kebijakan (policy). ${ }^{5}$ Oleh sebab itu, istilah kebijakan hukum dan politik hukum merupakan terminologi yang sepadan dan dipergunakan secara bergantian dengan merujuk pada makna yang sama.

Pengertian tentang politik hukum/kebijakan hukum didefinisikan secara berbeda oleh banyak ahli. Ada yang mengartikan politik hukum secara sempit sebatas kebijakan negara mengenai hukum yang berlaku (ius constitutum) sebagaimana tercermin dalam pendapat David Kairsy bahwa politik hukum merupakan kebijaksanaan negara untuk menerapkan hukum. ${ }^{6}$ Namun ada juga yang mengartikan secara luas seperti pendapatnya Teuku Mohammad Radhie yang menyatakan bahwa kebijakan hukum/politik hukum adalah suatu pernyataan kehendak penguasa Negara mengenai hukum yang berlaku di wilayahnya dan mengenai arah perkembangan hukum yang dibangun. Definisi ini mengambarkan bahwa pengertian politik hukum mencakup ius constitutum atau hukum yang sedang berlaku dan sekaligus ius constituendum atau hukum yang di cita-citakan berlaku di masa yang akan datang. ${ }^{7}$ Dalam penelitian ini kebijakan hukum yang dimaksudkan adalah kebijakan hukum tentang tanggung jawab TNCs dalam arti luas.

Apabila ditinjau dari berbagai peraturan yang ada di Indonesia maupun kebijakan yang dibuat oleh pemerintah tidak ditemukan pengaturan secara khusus tentang tanggung jawab TNCs atas pelanggaran hak untuk menikmati lingkungan hidup yang sehat di Indonesia. Berbagai peraturan yang ada hanya mengatur tentang tanggungjawab perusahan dalam pelestarian lingkungan tanpa membedakan antara perusahan nasional dan perusahaan transnasional (TNCs). Padahal keduanya memiliki karakteristik yang berbeda dalam banyak hal seperti dukungan modal, teknologi yang digunakan, dll, yang kesemuanya itu akan berpengaruh terhadap besar kecilnya kerusakan lingkungan yang ditimbulkan. Perusahaan TNCs yang notabene adalah perusahan-perusahaan yang didukung oleh modal yang besar dan teknologi yang super canggih pastilah akan menimbulkan kerusakan lingkungan yang besar dibanding perusahan nasional

${ }^{5}$ Muhammad Akib, Politik. Hukum Lingkungan: Dinamika dan Refleksinya Dalam Produk Hukum Otonomi Daerah, PT RajaGrafindo Persada, Jakarta, 2012, hlm. 1.

${ }^{6}$ David Kairsy (ed). The Politics of Law, A Progressive Critique, Pantheon Books, New York, 1990, hlm. xi.

${ }^{7}$ Moh. Mahfud MD, Politik Hukum, Edisi Revisi, Rajawali Pers, Jakarta, 2009, hlm. 1 
dengan kemampuan teknologi terbatas. Sehingga dapat dikatakan bahwa kebijakan hukum yang sekarang ini ada dan tertuang dalam berbagai peraturan perundang-undangan belum mengatur secara khusus tanggung jawab TNCs yang melanggar hak menikmati lingkungan hidup yang sehat di Indonesia.

Padahal UUD 1945 sebagai hukum tertinggi di Indonesia telah menjamin bahwa menikmati lingkungan hidup yang sehat merupakan hak setiap orang. Hal ini termaktub dalam Pasal 28H ayat (1) UUD 1945 yang berbunyi: Setiap orang berhak hidup sejahtera lahir dan batin, bertempat tinggal, dan mendapatkan lingkungan hidup yang baik dan sehat serta berhak memperoleh pelayanan kesehatan. Pasal 33 ayat (4) UUD 1945 juga mengamanatkan agar seluruh aktifitas perekonomian termasuk ekplorasi sumber daya alam harus memperharikan prinsip keberlanjutan dan berwawasan lingkungan. Selengkapnya Pasal 33 ayat (4) UUD 1945 berbunyi sebagai berikut: Perekonomian nasional diselenggarakan berdasar atas demokrasi ekonomi dengan prinsip keadilan, kebersamaan, efisiensi, berkelanjutan, berwawasan lingkungan, kemandirian, serta dengan menjaga keseimbangan kemajuan dan kesatuan ekonomi nasional. Berdasarkan ketentuan Pasal 33 (4) UUD 1945 jelas dapat dijadikan landasan hukum yang kuat untuk membuat kebijakan terhadap tanggung jawab TNcs atas pelanggaran hak untuk menikmnati lingkungan hidup yang sehat mengingat keberlangsungan pertumbuhan ekonomi nasional akan sangat bergantung pada keberlanjutan lingkungan yang sehat dalam artian termasuk pemanfaatan sumber-sumber alam secara berkelanjutan.

Perlunya Model Kebijakan Hukum terhadap Tanggung Jawab TNCs di Indonesia atas Pelanggaran Hak Menikmati Lingkungan yang Sehat di Indonesia

Berdasarkan beberapa definisi tentang kebijakan hukum atau politik hukum sebagaimana sudah disebutkan sebelumnya, Moh. Mahfud MD membedakan antara kebijakan hukum atau politik hukum dengan studi politik hukum atau studi kebijakan hukum. Menurut Mahfud, yang pertama (politik hukum atau kebijakan hukum) lebih bersifat formal pada kebijakan resmi sedangkan yang kedua (studi politik hukum atau studi kebijakan hukum) 
mencakup kebijakan resmi dan hal-hal lain yang terkait dengannya. ${ }^{8}$ Atau dengan kata lain studi politik hukum atau studi kebijakan hukum mencakup keseluruhan unsur dalam sistem hukum yang menurut Friedman unsur utama sistem hukum meliputi materi hukumnya, struktur hukumnya, dan budaya hukum.

Dalam perspektif hukum lingkungan, kesejahteraan yang menjadi tujuan politik hukum nasional yang berlandaskan pada prinsip-prinsip pengelolaan lingkungan yang diamanatkan oleh Pasal 33 UUD 1945 tersebut harus menjadi arahan dalam pembuatan dan pelaksanaan kebijakan lingkungan untuk menjamin agar kesejahteraan yang ingin dicapai mampu bertahan lama karena sumber daya alam (SDA) sebagai salah satu elemen pembangunan dapat dimanfaatkan secara berkelanjutan. Penyelenggaraan pembangunan nasional haruslah bersifat pro lingkungan atau melindungi lingkungan hidup sesuai dengan prinsip pembangunan berkelanjutan (sustainable development) yang menjamin kelangsungan hidup dan terpeliharanya daya dukung lingkungan untuk kehidupan generasi-genarasi selanjutnya.

Penguasaan oleh negara atas segenap sumber daya yang terdapat di dalam bumi, air, wilayah udara Indonesia serta segala kekayaan yang terkandung di dalamnya, haruslah dipergunakan hanya untuk sebesar-besarnya kemakmuran seluruh rakyat, bukan hanya kemakmuran untuk orang-per orang. Tujuan akhir dari kegiatan ekonomi yang paling pokok justru adalah terwujudnya ide masyarakat adil makmur berdasarkan pancasila dan UUD 1945. Dengan demikian yang harus mendapat mamfaat dari adanya usaha pemamfaatan kekayaan alam yang tersedia itu adalah seluruh rakyat, rakyat banyak, dan termasuk rakyat setempat. ${ }^{9}$

Selain Pasal 33, pasal lain yang berkaitan dengan jaminan konstitusional hak atas lingkungan hidup yang sehat diatur pula dalam Pasal 28H ayat (1) UUD 1945 yang berbunyi: Setiap orang berhak hidup sejahtera lahir dan batin, bertempat tinggal, dan mendapatkan lingkungan hidup yang baik dan sehat serta berhak memperoleh pelayanan kesehatan.

Hadirnya ketentuan Pasal 28H ayat (1) UUD 1945 tersebut telah menegaskan bahwa norma lingkungan hidup telah mengalami konstitusionalisasi menjadi materi muatan konstitusi sebagai hukum tertinggi. Dengan demikian, segala kebijakan dan tindakan pemerintah dan pembangunan haruslah tunduk pada

${ }^{8}$ Ibid.

${ }^{9}$ Jimly Asshiddiqie, Konstitusi Ekonomi, PT Kompas Media Nusantara, Jakarta, 2010, hlm. 282 
ketentuan mengenai hak asasi manusia atas lingkungan hidup yang baik dan sehat itu. Tidak boleh ada lagi kebijakan yang tertuang dalam bentuk undangundang ataupun peraturan di bawah undang-undang yang bertentangan dengan ketentuan konstitusional yang pro-lingkungan ini. ${ }^{10}$

Dengan demikian, secara konstitusional, Pembukaan, Pasal 33 dan Pasal 28H ayat (1) UUD 1945 merupakan acuan dan tujuan yang ingin dicapai dalam pengelolaan lingkungan di Indonesia yaitu pengelolaan lingkungan demi sebesarbesarnya kepentingan dan kemakmuran masyarakat Indonesia dengan tetap menjaga kelestarian alam. Oleh sebab itu, UUD 1945 sebagai hukum tertinggi di Indonesia harus dijadikan pedoman pokok di dalam mendesain kebijakan hukum tentang lingkungan di Indonesia. Menurut Jimly Asshiddiqie, adanya unsurunsur kebijakan yang pro lingkungan di dalam UUD 1945 itu menjadikan UUD 1945 sebagai salah satu green constitution di dunia, meskipun nuansa hijau masih sangat tipis (light green constitution). ${ }^{11}$

Adapun ruang lingkup kebijakan hukum yang dimaksud dalam penelitian ini adalah kebijakan negara (garis resmi) tentang hukum yang diberlakukan dan hukum yang seharusnya akan diberlakukan terhadap tanggung jawab TNCs atas pelanggaran hak menikmati lingkungan hidup yang sehat di Indonesia dalam rangka mencapai tujuan negara untuk menjamin perlindungan hak setiap orang untuk menikmati lingkungan hidup yang sehat sebagaimana sudah tercantum dalam Pasal 28(h) UUD RI 1945.

Untuk memahami sejauhmana komitmen suatu negara dalam mengatur pengelolaan lingkungan hidup guna menciptakan lingkungan hidup yang sehat bagi warga negaranya salah satunya dapat dilihat dari kebijakan hukum lingkungan yang dihasilkan dan Undang-Undang yang berkaitan dengan usaha yang dilakukan TNCs seperti Undang-Undang Nomor 32 Tahun 2009 tentang Perlindungan dan Pengelolaan Lingkungan Hidup, Undang-Undang Nomor 25 Tahun 2007 Tentang Penanaman Modal, Undang-Undang Nomor 40 Tahun 2007 tentang Perseroan Terbatas, Undang-Undang Nomor 22 tahun 2001 tentang Migas dan Gas Bumi, Undang-Undang Nomor 4 Tahun 2009 Tentang

${ }^{10}$ Jimly Asshiddiqie, Green Constitution: Nuansa Hijau Undang-Undang Dasar Negara Republik Indonesia Tabun 1945, Rajawali Pers, Jakarta, 2010, hlm. 91.

${ }^{11}$ Jimly Asshiddiqie, Konstitusi Ekonomi, Op. Cit., hlm. 282-283. 
Pertambangan Mineral Dan Batubara. Dari kebijakan hukum yang dituangkan ke dalam beberapa peraturan perundang-undangan yang ada itu akan dapat diambil suatu gambaran yang utuh mengenai berbagaimacam corak kebijakan dalam suatu negara apakah sudah memadai atau tidak dalam mencapai tujuan bernegara utamanya di bidang lingkungan hidup.

Adanya kekosongan kebijakan hukum terhadap tanggung jawab TNCs di Indonesia perlu untuk dibuat model kebijakan hukum yang seperti apakah yang dapat digunakan oleh pemertintah Indonesia dalam rangka untuk mencegah, menanggulangi dan memberikan perlindungan hukum terhadap hak menikmati lingkungan hidup yang sehat yang dilanggar oleh TNCs. Adapun model kebijakan hukum terhadap tanggung jawab TNCs di Indonesia dapat dilakukan melalui berbagai macam kebijakan sebagai berikut: pertama, pembaharuan peraturan yang relevan dengan tanggung Jawab TNCs di Indonesia. Kedua, pembentukan Institusi yang kompeten dalam mengimplementasikan tanggung jawab tersebut. Ketiga, mekanisme partisipasi masyarakat dalam keputusan pembuatan perijinan dan pengawasan.

\section{Instrumen Internasional dan Nasional yang Mengatur tentang Perilaku TNCs di Indonesia}

Untuk memberikan perlindungan hukum terhadap hak untuk menikmati lingkungan hidup yang sehat sangat penting bagi keberlangsungan kehidupan manusia, mengingat lingkungan yang sehat berpengaruh besar pada kehidupan manusia dan makluk hidup yang lainnya. Pelanggaran hak untuk menikmati lingkungan hidup yang sehat yang dilakukan oleh TNCs di Indonesia bukanlah masalah yang mudah untuk diatasi, hal ini disebabkan TNCs memiliki pengaruh yang besar dalam bidang ekonomi di Indonesia. Oleh karena itu, diperlukan adanya instrumen hukum internasional maupun nasional guna mengatur pertanggung jawaban TNCs di Indonesia.

\section{Instrumen Internasional yang Mengatur tentang Perilaku TNCs di Indonesia}

Indonesia sebagai anggota PBB berkewajiban untuk menghormati instrumen-instrumen internasional yang berlaku. Instrumen Internasional yang 
mengatur tentang perilaku TNCs di negara penerima modal (host state) dapat melalui dua mekanisme: Pertama, melalui perjanjian internasional yang mengikat langsung pada negara, sebagai konsekuensinya perjanjian ini juga mengikat kepada TNC yang ada di negara tersebut. Kedua, melalui hukum yang tidak mengikat (Soft law) yang secara langsung ditujukan kepada TNCs. ${ }^{12}$

Code Of Conduct On Transnational Corporation baru diselesaikan tahun 1990. Code of Conduct ini merekomendasikan bahwa TNCs seharusnya menghormati hukum nasional host state dan kebijakan ekonominya ${ }^{13}$, serta tidak mencampuri urusan dalam negeri host state. Namun demikian dalam perkembangannya setelah perang dingin berakhir yang ditandai dengan runtuhnya Uni Soviet telah mengubah suatu pola yang berbeda, yaitu adanya kecenderungan negara-negara berkembang berlomba untuk menarik investor asing, sehingga membutuhkan adanya reregulasi.

The OECD's 1976 Guidelines for Multinational Enterprises (yang direvisi tahun 2000) merekomendasikan TNCs untuk menghormati hak asasi manusia di negara penerima modal (host state) yang sesuai dengan kewajiban negara untuk memberikan perlindungan terhadap hak asasi manusis. ${ }^{14}$ Secara khusus Guidelines ini merekomendasikan TNCs untuk berpartisipasi menghilangkan adanya diskriminasi dan juga menghindari adanya pemaksaan di tempat kerja, ataupun tidak menggunakan tenaga kerja anak-anak. Namun demikian, guidelines tersebut tidaklah mengikat baik bagi negara ataupun TNCs untuk melaksanakan atau tidak. Guideline ini sifatnya tidak memaksa dan juga kurang mekanisme untuk penegakannya, karena sifatnya memang sementara.

Instrumen internasional lainnya yaitu: The ILO's 1977 Tripartite Declaration of Principles Concerning Multinational Enterprises and Social Policy yang merekomendasikan kepada negara sebagai anggota ILO untuk melaksanakan

12 Edwin C. Mujih, "Co-Deregulation of Multinational Corporation Operating in Developing Countries: Partnering Against Corporate Social Responsibility?”, (2008), vol. 16, African Journal of International and Comparative Law, hlm. 252-253.

13 David Kinley and Rachel Chambers, "The UN Human Rights Norms for Corporations: The Private Implications of the Public International Law”, (2006), vol.6, Human Rights Law Review, hlm. 451-452.

${ }^{14}$ Edwin C. Mujih, n. 62, hlm. 254. 
ketentuan dalam ILO ini kepada TNCs yang ada di negaranya. ${ }^{15}$ Dalam Deklarasi ini maupun Code of Conduct merekomendasikan TNCs untuk menghormati hak asasi manusia, dan menghormati hukum nasional host state. Dalam hal ini TNCs harus berusaha untuk mendorong negara penerima modal untuk melindungi hak asasi manusia dan tidak melakukan pelanggaran baik pelanggaran hak asasi manusia maupun hak untuk menikmati lingkungan yang sehat.

The UN Global Compact ${ }^{16}$ juga merupakan instrumen internasional yang ditujukan kepada TNCs. The UN Global Compact ditujukan untuk mendorong pelaku bisnis termasuk TNCs untuk melaksanakan 9 prinsip pokok dalam berbisnis, berkaitan dengan penghormatan hak asasi manusia, hak-hak buruh, dan perlindungan terhadap lingkungan, baik melalui mekanisme korporasi secara individul maupun melalui kebijkan publik di host state. Namun karena, kurangnya mekanisme monitoring dan lemahnya penegakan hukum, ${ }^{17}$ hal inilah yang menyebabkan korporasi melanggar hak-hak asasi manusia di host state. ${ }^{18}$ Memang suatu fakta bahwa PBB tidak memiliki mandat untuk melakukan monitoring ataupun melakukan pengawasan terhadap aktivitas yang dilakukan oleh korporasi di host state. ${ }^{19}$ Oleh karena itu sangat memungkinkan bagi TNCs untuk melakukan pelanggaran hak asasi dan hak menikmati lingkungan yang sehat.

${ }^{15}$ Lilian Aponte Miranda, "The Hybrid state-Corporate Enterprises and Violation of Indigenous Land Rights: Theorising Corporate Responsibility and Accountability under International Law”, (Spring, 2007), vol. 11, Lewis \& Clark.Law Review, hlm. 148.

16 A Guide to the Global Compact: A Practical Understanding of the Vision and Nine Principle $<$ http://www.unglobalcompact.org/content/Public Documents/gcguide.pdf> Accessed on, October 2010. These principles were centered generally around well-accepted standards of human rights, labour rights, and environmental issues, derived from the UN Declaration of Human Rights, the International Labour Organization Declaration on Fundamental Principles and Rights at Work, and the Rio Declaration on Environment and Development: (i) To support and respect the protection of internationally proclaimed human rights; (ii) To avoid complicity in human rights abuses; (iii) To uphold freedom of association and the effective recognition of the right to collective bargaining; (iv) To eliminate all forms of forced and compulsory labor; (v) To abolish effectively child labor; (vi) To eliminate discrimination with respect to employment and occupation; (vii) To support a precautionary approach to environmental challenges; (viii) To promote greater environmental responsibilities; and (ix) To encourage the development and diffusion of environmentally friendly technologies. See also,

17 Surya Deva, "Global Compact: A Critique of the U.N's 'Public Private' Partnership for Promoting Corporate Citizenship”, (fall. 2006), vol. 34, Syracuse Journal of International Law \& Comparative, p. 110. See also, Lisbeth Segerlund, "Thirty Years of Corporate Social Responsibility within the UN: From Code of Conduct to Norm". < http://archive.sgir.cu/upload/Segerlund thirty years of corporate.pdf $>$ Accessed on 22 August, 2010.

18 Evaristus Osheonebo, "The UN Global Compact and accountability of Transnational Corporations Separating Myth from Reality”, (April, 2007), vol.19, Fla.J.Int'l L., hlm. 9-10.

19 Cynthia A. William, "Civil Society Initiatives and Soft Law in the Oil and Gas industry", (WinterSpring, 2004), New York University Journal of International Law and Politic, hlm. 473. 
Terakhir, adalah the UN Norms yang mewajibkan kepada TNCs dan bentuk organisasi bisnis lainnya maupun terhadap subkontraktor dan para supplier untuk menghormati the UN Norm. ${ }^{20}$ The UN Norms dapat dikatakan lebih maju dibandingkan guidelines yang lain. Namun tidak dapat dipungkiri, bahwa UN Norm ini sifatnya juga tidak mengikat. Sekalipun the UN Norms ${ }^{21}$ mungkin dapat membantu pembentukan hukum kebiasaan internasional. Kalau UN Norm ini dapat menjadi hukum kebiasaan internasional, maka statusnya akan berubah dari tidak mengikat menjadi ketentuan yang mengikat. Lebih lanjut lagi the Ruggie Report menyediakan kerangka kerja untuk memfasilitasi tercapainya tujuan tersebut. ${ }^{22}$

\section{Instrumen Nasional yang Mengatur tentang Perilaku TNCs di Indonesia}

Kurangnya mekanisme penegakan hukum dan sulitnya penegakan hukum instrumen internasional sebagaimana dipaparkan sebelumnya, maka untuk mengisi kekosongan hukum sangat diperlukan adanya penegakan hukum oleh negara penerima modal (host state). Penegakan hukum nasional ini sebetulnya dapat melalui dua mekanisme, yaitu melalui mekanisme penegakan hukum yang dilakukan oleh negara asal TNCs (home state), dan yang kedua melalui mekanisme penegakan hukum yang dilakukan oleh host state sekalipun penegakan hukum ini masih mengalami banyak kendala seperti yang terjadi di Indonesia.

Akan tetapi inilah salah satu mekanisme yang memungkinkan untuk melakukan penegakan hukum yang telah dilanggar oleh TNCs, karena TNCs harus mentaati ketentuan hukum host state dan TNCs tidak kebal terhadap hukum host state. Hanya saja permasalahan dan kendala yang dihadapi, kadangkadang host state tidak memberikan sanksi terhadap TNCs yang telah melakukan pelanggaran hak asasi manusia ataupun melanggar hak menikmati lingkungan hidup yang sehat di host state, akan tetapi pemerintah di host state justru

${ }^{20}$ Michael K Addo, "Human Rights Perspective of Corporate Groups”, (Spring, 2005), vol. 37, Connecticut Law Review, hlm. 678.

${ }^{21}$ Sub-Commission on the Promotion and Protection of Human Rights, Fifty-fifth session, Commentary on the Norms on the responsibilities of transnational corporations and other business enterprises with regard to human rights .Lihat juga, U.N. Doc. E/CN.4/Sub.2/2003/12/Rev.2 (2003)

22 David Kinley, Justine Nolan and Natale Zerial, "The Politics of Corporate social Responsibility: Reflections on the United Nations Human rights Norms for Corporation". < http://www.unctad.org/en/docs/iteirf 2005 en.pdf > Accessed on 24 August, 2010. 
membantu untuk terjadinya pelanggaran tersebut. Oleh karena itu, model kebijakan hukum diperlukan dalam rangka mencapai tujuan negara sebagaimana tercantum dalam pembukaan UUD Republik Indonesia Tahun 1945.

Berbagai peraturan nasional Indonesia tidak mengatur secara langsung tentang tanggung jawab TNCs. Adapun berbagai peraturan yang mengatur tentang kegiatan usaha di Indonesia antara lain Undang-Undang Penanaman Modal, Undang-Undang tentang Perseroan Terbatas, Undang-Undang tentang Pertambangan Mineral dan Batubara, dan Undang-Undang tentang Minyak dan Gas Bumi dan undang-undang tentang Pengelolaan dan Perlindungan Lingkungan dan masih banyak lagi berbagai peraturan pemerintah ataupun peraturan menteri sebagai pelaksana undang-undang tersebut. Akan tetapi permasalahannya ialah berbagai peraturan perundang-undangan dan juga berbagai peraturan pemerintah dan peraturan menteri tersebut belum sinergis dalam implementasinya untuk menerapkan kebijakan hukum terhadap tanggung jawab TNCs di Indonesia.

Bukti bahwa berbagai peraturan di Indonesia hanya mengatur bentuk tanggung jawab perusahaan secara umum dalam hal pelestarian lingkungan dan belum mengatur secara khusus tentang tanggung jawab TNCs atas pelanggaran hak menikmati lingkungan yang sehat di Indonesia dapat ditemukan dalam beberapa peraturan sebagai berikut:

Pertama, Pasal 9 Undang-Undang Nomor 39 Tahun 1999 tentang Hak Asasi Manusia menyebutkan bahwa hak untuk hidup sebagai salah satu hak asasi manusia meliputi: (1) hak untuk hidup, mempertahankan hidup dan meningkatkan taraf kehidupannya, (2) hak hidup tenteram, aman, damai, bahagia, sejahtera lahir dan batin, dan (3) hak atas lingkungan hidup yang baik dan sehat. Apabila ada pihak-pihak yang merasa terlanggar haknya untuk menikmati lingkungan yang sehat, UU HAM memberikan hak kepada mereka untuk menuntutnya melalui Komisi Nasional Hak Asasi Manusia (Komnas HAM). Hal ini ditegaskan dalam Pasal 90 UU HAM yang berbunyi “Setiap orang dan atau kelompok yang memiliki alasan kuat bahwa hak asasinya telah dilanggar dapat mengajukan laporan dan pengaduan lisan atau tertulis pada Komnas HAM." 
Kedua, Pasal 16 huruf (d) Undang-Undang Nomor 25 Tahun 2007 tentang Penanaman Modal berbunyi "Penanam modal wajib untuk menjaga kelestarian lingkungan hidup." Sementara ketentuan Pasal 17 nya menegaskan, "Penanam modal yang mengusahakan sumber daya alam yang tidak terbarukan wajib mengalokasikan dana secara bertahap untuk pemulihan lokasi yang memenuhi standar kelayakan lingkungan hidup, yang pelaksanaannya diatur sesuai dengan ketentuan peraturan perundang-undangan". Dalam Undang-undang ini hanya secara umum menyebutkan penanaman modal, tetapi tidak secara khusus memberikan kewajiban kepada TNCs untuk tidak melanggar hak menikmati lingkungan hidup yang sehat.

Ketiga, Pasal 74 ayat (1 s.d 3) Undang-Undang Nomor 40 Tahun 2007 tentang Perseroan Terbatas menyatakan, "Perseroan yang menjalankan kegiatan usahanya di bidang dan/atau berkaitan dengan sumber daya alam wajib melaksanakan tanggung jawab sosial dan lingkungan. Tanggung jawab sosial dan lingkungan merupakan kewajiban Perseroan yang dianggarkan dan diperhitungkan sebagai biaya Perseroan yang pelaksanaannya dilakukan dengan memperhatikan kepatutan dan kewajaran. Perseroan yang tidak melaksanakan kewajiban tersebut dikenai sanksi sesuai dengan ketentuan peraturan perundang-undangan." Jelas dalam undang-undang ini hanya mewajibkan untuk penyediaan anggaran untuk tanggung jawab sosial dan lingkungan, tetapi juga tidak menyebutkan secara eksplisit bagaimana pertanggungjawaban yang harus dilaksanakan kalau Perseroan tersebut melakukan pelanggaran terhadap hak untuk menikmati lingkungan hidup yang sehat.

Keempat, Undang-Undang Nomor 32 Tahun 2009 tentang Perlindungan dan Pengelolaan Lingkungan Hidup sebagai peraturan pokok dalam pengelolaan lingkungan di Indonesia telah menetapkan langkah-langkah yang harus dilakukan bagi perusahaan dalam mengekplorasi sumberdaya alam Indonesia yang bertujuan untuk melindungi kelestarian lingkungan hidup guna menciptakan lingkungan yang sehat bagi seluruh warga negaranya. Langkahlangkah dimaksud terdiri atas: (i) perencanaan, (ii) pemanfaatan, (iii) pengendalian, (iv) pemeliharaan, dan (v) pengawasan. 
Apabila terjadi pelanggaran atas UUPPLH oleh perusahaan yang mengakibatkan rusak dan tercemarnya lingkungan, maka UU PPLH juga telah mengatur 3 (tiga) macam sanksi bagi perusahaan yang merusak lingkungan tersebut yaitu: a) Sanksi administratif diatur dalam Pasal 76 s.d Pasal 83 UU PPLH. Secara substantif isi dari pasal-pasal tersebut berisi ketentuan bahwa Menteri, gubernur, atau bupati/walikota sebagai pejabat administrasi negara diberi kewenangan untuk menjatuhkan sanksi administratif kepada penanggung jawab usaha dan/atau kegiatan jika dalam pengawasan ditemukan pelanggaran terhadap izin lingkungan. Namun demikian, pemberian sanksi administratif ini tidak membebaskan penanggung jawab usaha dan/atau kegiatan dari tanggung jawab pemulihan dan pidana; b) Sanksi perdata yang diatur dalam Pasal 87 dan Pasal 88 UUPPLH. Pasal ini mengatur mengenai tanggung jawab perusahan yang melakukan perbuatan melanggar hukum berupa pencemaran dan/atau perusakan lingkungan hidup yang menimbulkan kerugian pada orang lain atau lingkungan hidup diwajibkan membayar ganti rugi dan/atau melakukan tindakan tertentu; c) Sanksi pidana. Dalam UU PPLH, pertanggungjawaban pidana bagi pelaku tindak pidana lingkungan yang dilakukan perorangan diatur dalam Pasal 98 s.d Pasal 115. Sementara sanksi pidana bagi pelaku tindak pidana lingkungan yang dilakukan oleh badan hukum (korporasi) diatur dalam Pasal 116 s.d Pasal 120.

Namun demikian, Undang-Undang ini juga sama seperti Undang-Undang yang sudah disebutkan sebelumnya, tidak ada ketentuan yang secara langsung mengatur tentang tanggung jawab TNCs atas pelanggaran hak untuk menikmati lingkungan hidup yang sehat, sehingga ini perlu adanya suatu kebijakan hukum khusus yang dapat dijadikan landasan hukum yang kuat untuk melakukan penegakan hukum terhadap TNCs.

Kelima, Undang-Undang Republik Indonesia Nomor 22 Tahun 2001 tentang Minyak dan Gas Bumi. Bab II tentang asas dan tujuan khususnya di Pasal 2 UU ini menegaskan bahwa: "Penyelenggaraan kegiatan usaha Minyak dan Gas Bumi yang diatur dalam Undang-undang ini berasaskan ekonomi kerakyatan, keterpaduan, manfaat, keadilan, keseimbangan, pemerataan, kemakmuran bersama dan kesejahteraan rakyat banyak, keamanan, keselamatan, dan kepastian hukum serta berwawasan lingkungan." 
Sementara di dalam Pasal 40 ayat (3) nya mempertegas tentang kewajiban perusahaan untuk melakukan pencegahan dan penanggulangan pencemaran serta pemulihan atas terjadinya kerusakan lingkungan hidup, termasuk kewajiban pascaoperasi pertambangan. Namun sayangnya, tidak ada satu pasal pun dalam UU ini yang mengatur tentang sanksi apabila perusahaan melakukan perusakan dan pencemaran lingkungan.

Keenam, Undang-Undang Nomor 4 Tahun 2009 Tentang Pertambangan Mineral Dan Batubara. Di dalam UU ini setidaknya ada dua pasal yang mengatur berkaitan dengan kewajiban para pihak yang bergerak dalam usaha pertambangan mineral dan batubara. Pertama, Pasal 2 huruf (d) UU Nomor 4 Tahun 2009 menyatakan, "Pertambangan mineral dan/atau batubara dikelola berasaskan berkelanjutan dan berwawasan lingkungan". Kedua, Pasal 65 yang berbunyi, "Badan usaha, koperasi, dan perseorangan yang melakukan usaha pertambangan wajib memenuhi persyaratan administratif, persyaratan teknis, persyaratan lingkungan, dan persyaratan finansial."

Namun demikian, di dalam ketentuan sanksi tidak ditemukan pengaturan bagi badan usaha, koperasi, dan perseorangan apalagi TNCs yang melakukan usaha pertambangan yang melakukan pencemaran dan perusakan lingkungan. Hal ini tentu menjadi kontradiktif karena disatu sisi seluruh penyelenggara usaha pertambangan diwajibkan untuk menjaga kelestarian lingkungan namun apabila terjadi pelanggaran tidak ada ancaman sanksinya.

Dari berbagai peraturan perundang-undangan tersebut masih banyak keberpihakan terhadap kepentingan pemilik modal (TNCs) daripada kepentingan perlindungan hak untuk menikmati lingkungan hidup yang sehat. Selain itu, sekalipun dalam perundang-undangan tersebut juga sudah mengatur kewajiban yang harus dilkukan oleh si pelaku usaha untuk memberikan perlindungan lingkungan dengan mengalokasikan dana khusus, namun semua itu sifatnya umum dan tidak secara khusus ditujukan kepada TNCs. Perundang-undangan yang memiliki karateristik umum, kalau memang akan digunakan untuk mencapai suatu tujuan tertentu khususnya terhadap tanggung jawab TNcs atas pelanggaran hak menikmati lingkungan hidup yang sehat, maka diperlukan adanya suatu kebijakan hukum yang secara khusus ditujukan kepada TNCs, 
sepanjang kebijakan hukum tersebut tidak bersifat diskriminatif dalam artian adanya perlakuan perlindungan hukum yang sama terhadap pelanggaran hak menikmati lingkungan hidup yang sehat, baik itu dilakukan oleh TNCs atau dilakukan oleh perusahaan yang seratus persen merupakan modal nasional. Oleh karena itu, diperlukan adanya model kebijakan hukum terhadap tanggung jawab TNCs atas pelanggaran hak menikmati lingkungan hidup yang sehat di Indonesia.

\section{Penutup}

Hak untuk menikmati lingkungan yang sehat merupakan hak asasi manusia generasi ketiga yang merupakan hak komunal. Dalam perkembangannya di Indonesia, hak untuk menikmati lingkungan yang sehat sudah diakui sebagai hak konstitusi warga negara yang dicantumkan dalam Pasal $28 \mathrm{H}$, dan juga dicantumkan dalam Undang-undang HAM Indonesia, akan tetapi masih banyak terjadi pelanggaran yang dilakukan oleh TNCs di Indonesia.

Kebijakan hukum terhadap tanggung jawab TNCs di Indonesia atas pelanggaran hak menikmati lingkungan hidup yang sehat belumlah terintegrasi dalam berbagai peraturan perundang-undangan di Indonesia. Hal ini juga diperparah dengan lemahnya penegakan hukum di Indonesia. Berdasarkan penelitian ini ditemukan bahwa terjadi ketidak sinkronan antara peraturan sektoral satu dan lainnya berkaitan dengan kewajiban dan tanggung jawab TNCs di Indonesia. Oleh karena itu perlu adanya kebijakan hukum dan model kebijakan hukum terhadap tanggung jawab TNCs atas pelanggaran hak untuk menikmati lingkungan hidup yang sehat.yang dibuat oleh negara untuk memberikan suatu kepastian hukum dan juga memberikan arah kebijakan peraturan perundang-undangan Indonesia, sehingga keberadaan TNCs di Indonesia dapat memberikan kontribusi yang positif bagi peningkatan kesejahteraan rakyat Indonesia dan juga perlindungan lingkungan. 


\section{Daftar Pustaka}

A Guide to the Global Compact: A Practical Understanding of the Vision and Nine Principle <http://www.unglobalcompact.org/content/Public Documents/gcguide.pdf $>$ Accessed on October 2010.

Akib, Muhammad, Politik Hukum Lingkungan: Dinamikan dan Refleksinya Dalam Produk Hukum Otonomi Daerah, PT RajaGrafindo Persada, Jakarta, 2012.

Antonio, Cassese, International Law, New York, Oxford University Press, 2001.

Asshiddiqie, Jimly, Konstitusi Ekonomi, PT Kompas Media Nusantara, Jakarta, 2010.

Green Constitution: Nuansa Hijau Undang-Undang Dasar Negara Republik Indonesia Tahun 1945, Rajawali Pers, Jakarta, 2010.

"Demokrasi dan Hak Asasi Manusia" Materi yang disampaikan dalam studium general pada acara The st National Converence Corporate Forum for Community Development, Jakarta, 19 Desember 2005.

Barbara A., Frey, "The Legal and Ethical Responsibilities of Transnational Corporations in the Protection of International Human Rights Law" (1996), Vol. 6, Minnesota Journal of Global Trade.

Bruce, Broomhall, International Justice and the International Criminal Court: Between Sovereignty and the Rule of Law, New york, Oxford University Press, 2003.

Cynthia A., William, "Civil Society Initiatives and Soft Law in the Oil and Gas industry", (Winter-Spring, 2004), New York University Journal of International Law and Politic.

David, Kinley and Chambers Rachel, "The UN Human Rights Norms for Corporations: The Private Implications of the Public International Law", (2006), vol.6, Human Rights Law Review.

David, Kinley, Nolan Justine and Zerial Natale "The Politics of Corporate social Responsibility: Reflections on the United Nations Human rights Norms for Corporation". < http://www.unctad.org/en/docs/iteirf 2005_en.pdf $>$ Accessed on 24 August, 2010.

Edwin C., Mujih, "Co-Deregulation of Multinational Corporation Operating in Developing Countries: Partnering Against Corporate Social Responsibility?", (2008), vol. 16, African Journal of International and Comparative Law.

Evaristus, Osheonebo, "The UN Global Compact and accountability of Transnational Corporations Separating Myth from Reality", (April, 2007), Vol. 19, Fla.J.Int'l L

Halpern, Iris, "Tracing the Contours of Transnational Corporations' Human Rights Obligation in the Twenty-First Century", (2008). Vol. 14, Buffalo Human Rights Law Review. 
Irfan Islami, M., Prinsip Prinsip Perumusan Kebijakan Negara, Bumi Aksara, Jakarta, 2003.

Jennifer A A Healthy, Down and Ecologically Balance Environment: An Argument for A Third Generation Right", (Spring, 1993), vol. 3, Duke Journal of Comparative E International Law.

Kairsy, David, (ed)., The Politics of Law, A Progressive Critique, Pantheon Books, New York, 1990.

Lilian Aponte, Miranda, "The Hybrid state-Corporate Enterprises and Violation of Indigenous Land Rights: Theorising Corporate Responsibility and Accountability under International Law", (Spring, 2007), Vol. 11, Lewis EClark.Law Review.

Lisbeth, Segerlund, "Thirty Years of Corporate Social Responsibility within the UN: From Code of Conduct to Norm". < http://archive.sgir.cu/upload/ Segerlund_thirty years of corporate.pdf $>$ Accessed on 22 August, 2010.

Mahfud MD., Moh., Politik Hukum, Edisi Revisi, Rajawali Pers, Jakarta, 2009.

Martin, Dixon, Text Book on International Law, London, Blackstone Press Limited, 2000.

Michael K., Addo, “Human Rights Perspective of Corporate Groups”, (Spring, 2005), Vol. 37, Conn.ecticut Law Review.

Nugroho Dwijowijoto, Riant, Kebijakan Publik: Formulasi, Impelentasi dan Evaluasi, Elex Media Komputindo, Jakarta, 2003.

Natso Taylor, Saito, "Beyond Civil Rights: Considering 'Third Generation International Human Rights Law in the United States", (1997), Vol. 28, University of Miami Inter-American Law Review. .

Rebecca Kathleen, Atkins, "Multinational Enterprises and Workplace Reproductive Health: Extending Corporate Social responsibility", (January, 2007), Vol. 40, Vanderbilt Journal of Transnational Law.

Ruppel, Oliver C. "Third Generation Human Rights and the Protection of the Environment in Namibia". p.2. < http://www.kas.de/upload/ uuslandshomepage/namibia/Human Rights/ruppel 1.pdf> Diakses tanggal 28 Agustus, 2010

Surya, Deva, "Global Compact: A Critique of the U.N's 'Public Private' Partnership for Promoting Corporate Citizenship", (Fall. 2006), Vol. 34, Syracuse Journal of International Law $\mathcal{E}$ Comparative.

Thomas T., Ankersen \& Ruppert Thomas K., "Defending the Polygon: the Emerging Human Right to Communal Property", (Winter, 2006), Vol. 59, Oklahoma Law Review.

U.N. Doc. E/CN.4/Sub.2/2003/12/Rev.2 (2003) 
W., Joe, (Chip) Pitt III, "Corporate Social Responsibility: Current Status and Future Evolution", (Spring, 2009), vol. 6, Rutgers Journal Of Law \& Public Policy.

Undang-Undang Dasar Negara Republik Indonesia Tahun 1945

Undang-Undang Nomor 39 Tahun 1999 tentang Hak Asasi Manusia

Undang-Undang Nomor 32 Tahun 2009 tentang Perlindungan dan Pengelolaan Lingkungan Hidup

Undang-Undang Nomor 25 Tahun 2007 Tentang Penanaman Modal

Undang-Undang Nomor 40 Tahun 2007 tentang Perseroan Terbatas

Undang-Undang Nomor 22 tahun 2001 tentang Migas dan gas Bumi

Undang-Undang Nomor 4 Tahun 2009 Tentang Pertambangan Mineral Dan Batubara

Universal Declaration of Human Rights

International Covenant on Economic, Social and Cultural Rights (ICCPR)

International Covenant on Economic, Social and Cultural Rights ((ICESCR)

Stockholm Declaration

Rio Declaration

Code of Conduct on Transnational Corporations

Global Compact 